\title{
Surgical Technique of Small Bowel Transplantation in a Large Animal Model
}

\author{
Martin Oliverius, Dušan Král ${ }^{1}$, Eva Honsová ${ }^{2}$, Alena Lodererováa ${ }^{2}$ Michal Kudla, \\ Petr Baláž, Alexandros Valsamis, Jiř́ Ćáp ${ }^{3}$
}

\author{
Department of Transplant Surgery, Institute for Clinical and Experimental Medicine, Prague \\ ${ }^{1}$ Libuš Veterinary Hospital, Prague \\ ${ }^{2}$ Department of Clinical and Transplant Pathology, \\ Institute for Clinical and Experimental Medicine, Prague \\ ${ }^{3}$ Department of Anesthesia, Resuscitation and Intensive Care, \\ Institute for Clinical and Experimental Medicine, Prague
}

Received February 9, 2009

Accepted January 19, 2010

\begin{abstract}
An experiment was carried out on pigs during preparation of a clinical project of intestinal transplantation. The objective of this study was to find the best surgical technique of vascular and intestinal anastomosis in different experimental settings (animals with and without immunosuppression) which could have a major impact on everyday veterinary practice. Transplantation was performed in 43 pigs. In the surgical part of the experiment we examined the most suitable surgical technique of vascular anastomosis. A running continuous single-layer seromuscular suture was used for all types of intestinal anastomoses. With regard to vascular anastomosis, the animals were divided into two groups. In group $1(\mathrm{n}=18)$ one animal was both donor and recipient of the intestinal graft. Anastomoses were constructed to the mesenteric vessel bed. In group $2(n=25)$, one animal was the graft donor and another was the graft recipient, with revascularization to the central vessel bed. In the second part of the study, we examined the impact of immunosuppressive drug administration on acute cellular rejection and animal survival. Animals that died due to technical failure and reasons unrelated to transplantation were excluded from the evaluation (19 pigs). A total of 24 pigs were included in the second part of the study. The animals were divided into four experimental groups. Group A - autotransplantation $(n=3)$, group B - allotransplantation on tacrolimus monotherapy $(n=7)$, group $C$ on combined immunosuppression with tacrolimus and sirolimus $(n=8)$, and control group $\mathrm{D}$ - without immunosuppression $(n=6)$. Results: A high rate of vascular complications occurred in the first group; $67 \%$ (12 out of 18 ). In the second group, the rate of complications was reduced to $12 \%$ ( 3 out of 25). In the second part of the study the shortest survival was found in group D and the longest in group A. In neither of the immunosuppressed groups $(\mathrm{B}+\mathrm{C})$ did we find any significant difference in survival. No complication with the healing of intestinal anastomosis was found in any group. In conclusion we can state the single-layer continuous running suture was safe for all kinds of intestinal anastomoses. Vascular reconstruction to the central vessels was safer for graft survival.
\end{abstract}

Sus scrofa domestica, intestinal transplantation, animal experiment, vascular anastomosis, intestinal anastomosis, single-layer continous running suture

Intestinal transplantation is currently a standard method of treatment for patients in whom parenteral nutrition therapy for the short bowel syndrome failed, and for patients with lifethreatening abdominal pathology (Pascher et al. 2008; Ruiz et al. 2007). In preparation of launching a clinical programme of bowel transplantation in the Czech Republic, an extensive study of small bowel transplantation in pigs was conducted. One of the aims of our study was to test various surgical techniques under demanding conditions due to immune changes associated with allotransplantation and immunosuppression, and to see which of these techniques could be employed in veterinary medicine.

Swine are used as a standard model for organ transplantations because they are relatively resistant to immunological insult after transplantation. The gastrointestinal tract of swine shows considerable anatomical differences from humans but analogous physiological

Address for correspondence:

MUDr. M. Oliverius

Transplant Surgery Department

Institute for Clinical and Experimental Medicine

Vídeňská 1958/9

CZ-14 00 Prague 4, Czech Republic

Phone: +420 721351528

Fax: +420261362 822

E-mail:maol@ikem cz

http://www.vfu.cz/acta-vet/actavet.htm 
function, probably because they are true omnivores and have dietary preferences similar to humans (Gatti et al. 1994).

\section{Materials and Methods}

In the experiment female outbred pigs Sus crofa domestica were used, weighing 30-35 kg. All experiments were carried out at an accredited animal unit of the Experimental Department of the Institute for Clinical and Experimental Medicine in Prague while complying with applicable standards for handling laboratory animals as stipulated by the Act 246/92 Coll. according to the accredited experimental protocol of the Ministry of Health of the Czech Republic No. 1/2006 (Act 246/1992 Collection of Laws against cruelty to animals, in current wording. Collection of Laws, 1992, No. 50, p. 1284).

Variables are presented as mean and standard error of the mean. Mean survival rates among groups were tested by one-way ANOVA and pair-wise comparisons were done by orthogonal contrasts. For the ACR-score KruskalWallis one-way ANOVA was used. All calculations were done by SYSTAT, statistical tests were two-tailed and 5\% significance level was applied.

Anaesthesia, analgesia, and euthanasia of experimental animals

Prior to all surgical procedures, the animals were pre-treated with azaperone $4 \mathrm{mg} / \mathrm{kg}$ b.w. (Stresnil ${ }^{\circledR}$, Janssen Pharmaceutical, Ireland) $+10 \%$ ketamine $10 \mathrm{mg} / \mathrm{kg}$ b.w. (Narketan ${ }^{\circledR}$, Vétoquinol, France) + atropini sulfas monohydricus $0.01 \mathrm{mg} / \mathrm{kg}$ b.w. (Atropin Biotika ${ }^{\circledR}$, Hoechst - Biotika, Czech Republic).

General anaesthesia was induced using intravenous phentanyl $0.1 \mathrm{ml} / \mathrm{kg} \mathrm{b.w.} \mathrm{(Fentanyl} \mathrm{Torrex}{ }^{\circledR}$, Torrex Chiesi Pharma GmbH, Austria) + midazolam 0.1mg/kg b.w. + propophol approximately $3 \mathrm{mg} / \mathrm{kg}$ b.w. (Propofol, Fresenius $^{\circledR}$, Fresenius Kabi, Austria) until the onset of the effect. Orotracheal intubation under topical anaesthesia with lidocain (Xylocaine 10\% Spray ${ }^{\circledR}$, Astrazeneca, Switzerland), in the sternal position using a modified Miller laryngoscope blade was used with a modified (extended) endotracheal cannula No. 7.0-8.5 with a sealing cuff. General anaesthesia was maintained using an inhalation mixture of air $+\mathrm{O}_{2}+$ isoflurane 1-2\% (Isofluran Nicholas Piramal $^{\circledR}$, Torrex Chiesi Pharma GmbH, Austria), continually enhanced by continuous i. v. phentanyl (Fentanyl Torrex ${ }^{\mathbb{R}}$, Torrex Chiesi Pharma GmbH, Austria) at the dose of $0.2 \mathrm{ml} / 1 \mathrm{~kg} / \mathrm{h}$ and not requiring the use of curarimimetics. Mechanical ventilation was provided using a Chirana Venar Media UPV device (Chirana, Prague, Czech Republic). Vital functions during anaesthesia were monitored using five-lead ECG as modified by Kaplan; oxygen saturation analysis was performed using a percutaneous nasal probe. Body temperature was measured with an oesophageal probe. For arterial blood pressure measurements, the brachial artery and, when inaccessible, the carotid artery in the neck was cannulated (Arrow $20 \mathrm{Ga}, 12 \mathrm{~cm}$ ). Central venous pressure was measured using a cannula tunnelled into the jugular vein (Arrow $7 \mathrm{Fr}, 20 \mathrm{~cm}, 1$ lumen). The cannula was tunnelled up to behind the animal's ear where it was fixated by suture and used for blood sampling. Protocol blood sampling was taken at postoperative days $0,3,5,7,10,14,20,28,30$ for further study purposes.

Infusion therapy was adjusted to the central venous pressure measured in order to maintain pre-clamping values at $10-13 \mathrm{~cm} \mathrm{H}$ O. A solution of plasma expanders 6\% HES (Voluven ${ }^{\circledR}$ inf., Fresenius Kabi, Germany) and isotonic solution (PlasmaLyte ${ }^{\circledR}$, Baxter, Czech Republic) was applied continually at $2 \mathrm{ml} / \mathrm{kg} / \mathrm{h}$. Protected coagulum was obtained using broad-spectrum antibiotic amoxicillin with clavulanic acid (Synulox Veterinary ${ }^{\circledR}$, Pfizer, United Kingdom) $30 \mathrm{mg} / \mathrm{kg}$ b.w. prior to incision. Systemic heparinum natricum $2000 \mathrm{IU}$ (Heparin ${ }^{\circledR}$, Zentiva, Czech Republic), was administered prior to vascular clamping.

For postoperative pain control we used the opioid anaesthetic butorphanoli hydrogenotartras (Torbugesic ${ }^{\circledR}$, Fort Dodge Animal Health, USA) at a dose of $0.05 \mathrm{mg} / \mathrm{kg}$ i. m. in combination with the non-steroid antiinflammatory drug carprofenum (Rimadyl ${ }^{\circledR}$, Vericore Ltd, UK) at a dose of $2-5 \mathrm{mg} / \mathrm{kg}$ i.m. at a 12 -h interval. Rimadyl administration was continued at a dose of $2 \mathrm{mg} / \mathrm{kg}$ i.m. every $24 \mathrm{~h}$ for 2 to 3 days or longer, when clinical signs of pain were present.

On post-transplant days 1 to 3, a broad-spectrum antibiotic (Synulox Veterinary ${ }^{\circledR}$ ) was administered at standard dosage.

Animals surviving until day 30 of the experiment were sacrificed by inducing deep anaesthesia with thiopental (Thiopenthal Valeant ${ }^{\mathbb{B}}$, VUAB Pharma a.s., Czech Republic) and cardiac arrest with $10 \%$ potassium chloride solution.

Surgical technique of transplantation

A detailed description of the surgical technique of harvesting, preservation, and suturing of vascular anastomosis was published elsewhere (Oliverius et al. 2009). Briefly, after opening the abdominal cavity, the vascular pedicle of the mesenteric root was mobilized while sparing the origin of the ileocolic vessel running lateral to the snaillike large bowel. Upon clamping, the vessels below the origin were transected and the whole graft on backtable was perfused with the HTK perfusion solution (Custodiol ${ }^{\circledR}$, Methapharm, Canada). After 2-h cold ischemia, the graft was transplanted to another animal. With the second type of transplantation, one animal was used as the donor of the entire graft, which had been harvested at the vascular pedicles of the aorta and portal vein. Those vessels were sutured to the recipient aorta and vena cava inferior during transplantation (Plate XIV, Fig. 1).

Gastrointestinal tract reconstruction was undertaken in the oral segment by connecting the recipient's blinded jejunal stump with the proximal jejunal loop of the graft using side-to-side anastomosis. The oral end of the graft was closed using purse-string suture and its antimesenteric side was brought up through a hole in the right 
subcostal abdominal wall as so-called chimney jejunostomy serving for clinical monitoring and protocol biopsy for further purposes of the experiment. The stoma was fixated with four stitches from the seromuscular layers of the intestinal wall, and the peritoneum and fascia of the abdominal wall. Upon stoma opening, single stitches placed across the whole layer were used to fixate it to the skin.

The aboral part of the terminal ileal graft was sutured end-to-end to the recipient terminal stump of ileum. All anastomoses were constructed using single-layer monofilament absorbable suture PDS 3/0 (polydioxanone, Johnson and Johnson, USA). The anastomosis started in the area of the mesenteric root and the first stitch was knotted after placing the suture across both ends. Using the longer part of the filament, we continued by placing stitches on only the seromuscular part of the bowel wall at either side at a 3-5 $\mathrm{mm}$ interval. The needle was emerged $1 \mathrm{~mm}$ from the cut edge of enterotomy and we took care never to include the mucosa. On completing the suture of the whole circumference, the anastomosis was knotted to the free part of the filament (Plate XIV, Fig. 2).

This technique of anastomosis construction was used in all cases.

To prevent the development of gastrectasia, which may result in respiratory insufficiency shortly after surgery, gastrostomy was undertaken in all animals using a permanent balloon catheter sutured by the conventional Witzel technique to the ventral aspect of the stomach and brought out through a puncture opening in the abdominal wall in the left subcostal area. Except for stomach decompression on the first postoperative day, gastrostomy was used for defined drug administration until the end of the study.

As standard procedure, the abdominal cavity was closed with continuous absorbable suture PDS loop 2/0 (Johnson and Johnson, USA) placed $1.5 \mathrm{~cm}$ from the margin across the whole layer. The subcutaneous tissue was adapted using continuous running suture 3/0 Vicryle (Johnson and Johnson, USA) and the skin was sutured with single monofilament stitches.

Animals surviving 30 days of the experiment were sacrificed and autopsied. At autopsy, the number of adhesions in the abdominal cavity was evaluated, and healing in terms of patency. Special attention was paid to assessing signs of inflammation, particularly at the site of intestinal anastomoses which were exposed to normal chow for a long time.

Postoperative nutrition

Energy requirements during the first two postoperative days were met by infusion of glucose and amino acids. Enteral feeding was started gradually through the gastric stoma using a saccharide solution from the second day, together with parenteral infusion depending on diuresis and overall condition. In uneventful postoperative course, all animals resumed the complete chow for large laboratory animals within 5 days.

\section{Postoperative monitoring}

The total duration of the experiment was scheduled for 30 post-transplant days. The overall clinical condition, weight and temperature were measured regularly according to the protocol (postoperative day 3, 5, 7, 10, 14, $20,28,30)$. Special attention was given to the visual appearance of the stoma, amount and nature of stoma output. Basic laboratory data, i.e., blood count, creatinine and mineral levels and, where necessary, acid base balance, were obtained from all animals for the first three postoperative days and as needed later according to the postoperative course. In the event of clinical manifestations of respiratory infection, secretion from nostrils was obtained for culture and sensitivity determination.

Immunosuppression

Induction therapy or corticosteroids were not administered. Immunosuppression consisted of tacrolimus (Prograf $^{\circledR}$, Astellas, Ireland) and sirolimus (Rapamune ${ }^{\circledR}$, Weyeth Pharmaceutical, United Kingdom). Immunosuppression therapy (in group B and C) was initiated with administration of tacrolimus during graft reperfusion at a dose of $0.3 \mathrm{mg} / \mathrm{kg}$. Beginning with the first postoperative day in group B, oral tacrolimus 0.6 $\mathrm{mg} / \mathrm{kg}$ was administered in two doses at a 12-h interval given via a gastric tube, with the aim of maintaining a tacrolimus concentration of $15+/-5 \mathrm{ng} / \mathrm{ml}$. Group C was administered oral tacrolimus $0.1 \mathrm{mg} / \mathrm{kg} / \mathrm{day}$ in two doses, and sirolimus at a single dose of $0.1 \mathrm{mg} / \mathrm{kg} /$ day to maintain tacrolimus and sirolimus levels at $7-10 \mathrm{ng} / \mathrm{ml} \mathrm{and}$ 5-10 ng/ml, respectively.

\section{Histology}

For other purposes of the experiment, specimens of intestinal tissue for histology were obtained at 30 min after graft reperfusion. Jejunostomy biopsy specimens were also obtained on days 3, 5, 7, 10,14, 20, 28, and 30 of the experiment under direct vision using biopsy forceps (Radial jaw Jumbo biopsy forceps, Boston Scientific, USA). Upon fixation with formalin, biopsy specimens were embedded in paraffin using standard method and stained with haematoxylin-eosin. To assess the extent of rejection-induced injury, the criteria related to experiments with large animals in modification incorporating experience from human pathology were used (Murase et al. 1990; Alessiani et al. 2003; Ruiz et al. 2004). Morphological features of acute cellular rejection (ACR) included the presence of inflammatory cellulization in the mucosal lamina propria in combination with varying degrees of crypt damage. Crypt damage involves decreased amounts of mucus, increased epithelial cell basophilia with so-called altered nuclei with hyperchromasia. Diagnostic features of moderate injury include apoptotic bodies as correlates of death of individual epithelial cells. Severe injury is characterized by crypt destruction and may be accompanied by bleeding into the intestinal wall resembling haemorrhagic necrosis. The extent of rejection-related changes was quantified using the following scale: 0 (no morphological features of acute cellular rejection), 1 (mild ACR), 2 (moderate ACR), 3 (severe ACR) (Plates XV and XVI, Figs 3-5). 


\section{Results}

A total of 43 pigs were operated on. The use of the first technique of vascular reconstruction, with the graft anastomosed to a narrow five-millimetre recipient mesenteric artery, was often associated with occlusion due to its kinking or torsion followed by immediate death of the experimental animal. In the first group $(n=18)$ we lost 12 out of 18 pigs $(67 \%)$. In the second group where the vascular inflow and outflow of anastomosis was connected to the central vascular system (inferior vena cava and aorta) we lost only three animals (3 out of $25 ; 12 \%)$ due to anastomotic bleeding. For the second part of the experiment we excluded all animals that died in connection with transplantation within the first three postoperative days due to technical failure during the "learning curve" period (anastomotic occlusion, bleeding). We also excluded animals that died for reasons unrelated to transplantation (bronchopneumonia, anaphylactic shock after antibiotic administration). Data of a total of 24 pigs surviving for varying times of the experiment were analyzed.

The longest survival time was found in the group of animals undergoing autotransplantation (group A). The shortest survival rates were noted in animals with allotransplantation without immunosuppression (group D). All these animals gradually developed acute cellular rejection with mucosal necrosis, bacterial translocation and sepsis. Animals receiving immunosuppression (groups $\mathrm{B}$ and $\mathrm{C}$ ) survived for varying periods of time. Regarding overall survival, significant differences at $p$ levels $<0.01,0.05$, and 0.01 were demonstrated between groups $\mathrm{A}, \mathrm{B}$, and $\mathrm{C}$ versus $\mathrm{D}$, respectively (Fig. 6).

No complication related to intestinal anastomosis healing was found. Anastomoses of all the autopsied animals were completely healed without any sign of anastomotic leak. Mucosal layers were perfectly adapted and healed along the whole circumference. No anastomotic leaks were found even in animals of group D that developed severe rejection involving the whole of mucosa.

As regards the surgical wound healing, a temporary ascites oozing from the abdominal incision closure was observed in six animals ( 2 in group C and 4 in group D) due to extensive disruption of lymphatic vessels, which healed gradually over a period of two to four days. There was no case of impaired abdominal wall healing resulting in organ evisceration. Development of incision hernia was observed in two animals (both of group B).

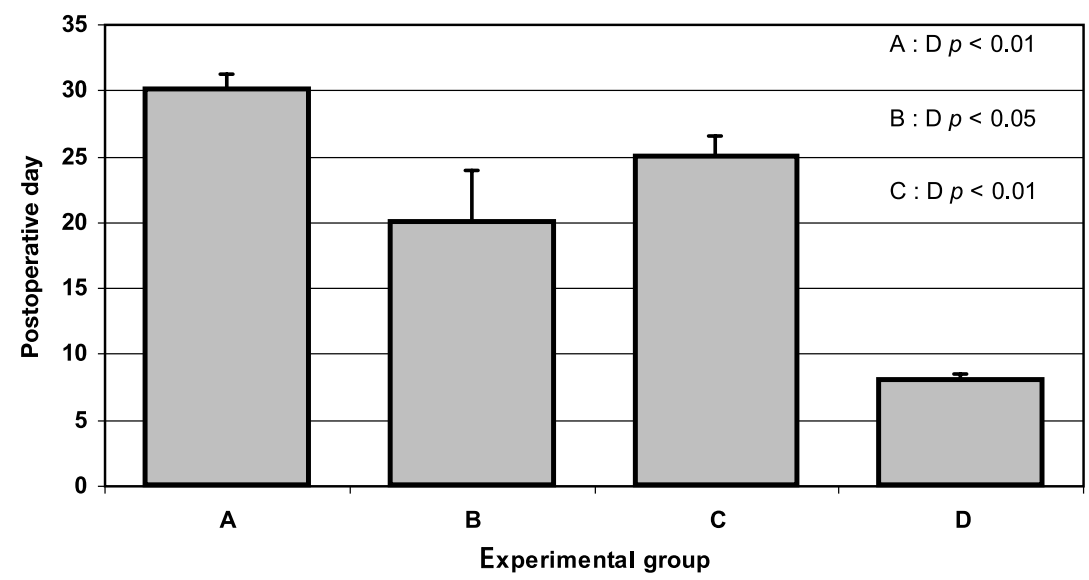

Fig. 6. Mean survival rates of experimental animals in individual groups. (A- autotransplantation; Ballotransplantation with tacrolimus monotherapy; C- allotransplantation with tacrolimus and sirolimus therapy; D- allotransplantation without immunosuppression) 


\section{Discussion}

For transplantation to be completed successfully, it is absolutely critical to master the surgical technique of graft harvesting, preservation and suture. In experimental papers, this technical error is reported in 10-50\%, especially in the "learning curve" period (Alessiani et al. 1997; Calleja-Kempin et al. 1998).

The aim of the experiment was to achieve the longest survival possible. It was the vascular anastomosis that posed most difficulty to us. When using the first technique of transplantation, with the animal being the donor and recipient at the same time, the thin vascular anastomosis was associated with recurrent vascular complications resulting in graft loss. These outcomes were presented in detail elsewhere (Oliverius et al. 2009).

Small bowel transplantation poses a major traumatic and, subsequently, immunological insult to the whole body. For the purposes of surgical technique evaluation, digestive anastomosis construction using continuous single-layer seromuscular suture offers quite unique experimental conditions, with the option to correlate the outcomes with autopsy results. In the group of animals undergoing allotransplantation, a marked reaction between the graft and recipient begins to occur virtually from the start of reperfusion. Unless therapeutically modulated, this reaction eventually develops into acute cellular rejection, resulting in cell- and hormone-induced graft destruction. This is, from the very beginning, associated with impaired defence capacity of the intestinal mucosa, manifesting itself by increased bacterial translocation, resulting in rapid development of sepsis and loss of the animal. These findings illustrate well the histological changes in terms of progressive rejection of up to grade III, observed in all $\mathrm{D}$ group animals. In all cases, acute rejection resulted in death of the animal within seven to nine post-transplant days. Various forms of rejection were also seen in the group of animals receiving immunosuppression. Statistical analysis revealed no significant difference in the extent of rejection between group B (tacrolimus in monotherapy) and group C (immunosuppression in combination) (Fig. 7).

The experimental conditions induced in group D (allotransplantation without immunosuppression) represent a critical stressful situation, associated with massive release of inflammatory cytokines (TNF-alpha and IF-gamma in particular) and the development of cell-mediated immunity which we measured during the protocol biopsies. The situation is aggravated even more by bacterial translocation and impaired integrity of the intestinal wall.

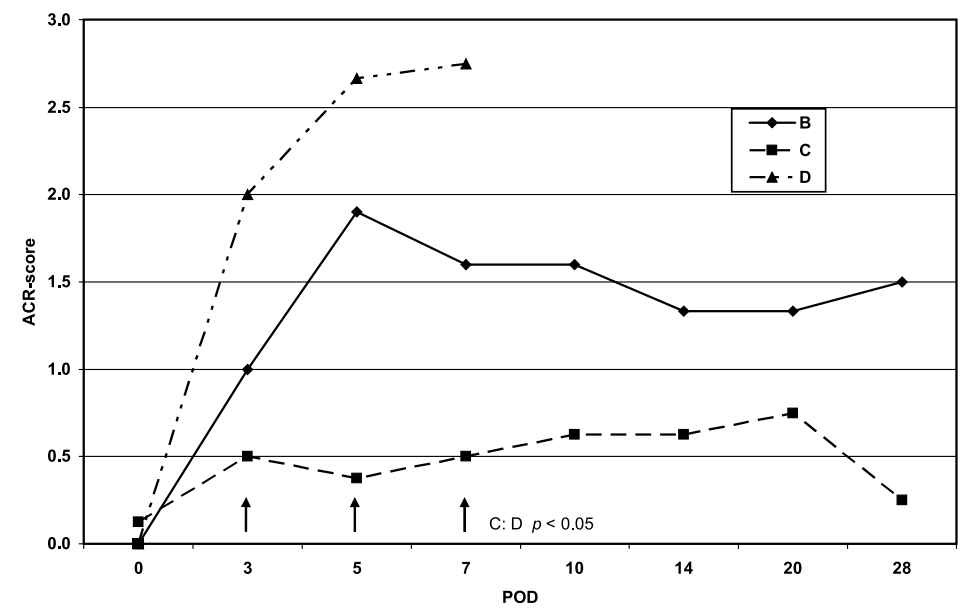

Fig. 7. Degree of acute cellular rejection in individual groups of experimental animals over time (ACR acute cellular rejection score -rejection grade (0-3); POD - postoperative days) 
It should be noted, however, that intestinal anastomosis healing was not impaired in a single animal of this group. The relevant human and veterinary literature includes several reports of techniques of suturing digestive anastomoses (Ellis on 1998; Brown 2003). The method of omentalisation, often employed in veterinary medicine, is not used in human medicine for ensuring digestive tract anastomoses. The importance of the omentum for healing lesions in the abdominal cavity has been largely discussed and well documented. However, omental fixation in the anastomotic area carries the risk of undesirable adhesions potentially resulting in stenosis and subsequent ileus. A recently published comparative study documents identical outcomes of the intestinal anastomoses healing with and without omentalisation (Crha et al. 2008). Generally, most surgical techniques of anastomosis construction used to date have been associated with a very good outcome and their use is dependent of the surgeon's preferences. Several critical preconditions must be met for proper healing of any anastomosis within the digestive tract. There must not be any tension within the anastomosis suture, good perfusion of the margins must be maintained, and the mucosa must not be within the anastomotic wall. Only the serosal surface provides good conditions for healing (Hendlung 2002). Our technique of anastomosis using single-layer continuous seromuscular suture has proved to be completely safe, less time-consuming and, eventually, also less costly (only a single filament is needed for the whole anastomosis). Similar results have been already proven in an experiment on dogs (Weisman et al. 1999). In our view, an advantage in terms of pathophysiology healing is minimizing the pressure on the anastomosis, which is evenly distributed along the whole circumference allowing it to match intestinal peristalsis. Even distribution of pressure is also advantageous because it results in minimal ischemia of the anastomosis margins, a crucial factor for healing. Another advantage is perfect mucosal adaptation which is never included into the anastomosis, and hermetic alignment of both serosas allowing their healing. Yet another advantage is the reduced amount of foreign material on the anastomotic surface as there are no single individual knots that might potentially result in the surrounding tissue response. Due to the experimentally induced conditions, the anastomoses were exposed to an extreme situation as a result of cellular rejection of varied intensity. Under these conditions, we expected impaired healing of the intestinal anastomosis with subsequent dehiscence, which, however, was not seen in any of the experimental groups. The findings of our experiments have been employed in everyday veterinary practice and have been used successfully in the surgical treatment of other animals as experienced by the second author.

\section{Chirurgická technika transplantace tenkého střeva na velkém zvířecím modelu}

V rámci přípravy na zahájení programu transplantace tenkého střeva jsme provedli velký experiment na zvírratech. Cílem naší studie bylo posoudit odlišné chirurgické techniky konstrukce cévní a střevní anastomózy v odlišných podmínkách experimentu (u zvířat s a bez podávané imunosuprese), které by mohly mít přínos pro veterinární praxi. Celkem jsme provedli 43 transplantací. V chirurgické části experimentu jsme zkoumali nejvhodnější techniku cévní anastomózy. Ve všech případech byla ke konstukci střevních anastomóz použita technika jednovrstevného pokračujícího seromuskulárního stehu. Zvířata jsme rozdělili do dvou skupin: ( $n=18$ prasat), kdy jedno zvíře je zároveň dárcem i prŕjemcem štěpu $\mathrm{z}$ druhého zvířete. $\mathrm{V}$ druhé skupině $(\mathrm{n}=25$ prasat $)$, je jedno zvíŕe dárcem štěpu a druhé př́ijemcem, s cévní rekonstrukcí na centrální cévy. Pro účely druhé části studie jsme zkoumali vliv podávané imunosuprese na vznik akutní celulární rejekce a přežívání zvířat. Zvírrata, která zemřela $\mathrm{v}$ důsledku technických chyb a prríčin nesouvisejících s transplantací jsme z hodnocení vyřadili (19 prasat). V této části studie jsme hodnotili celkem 24 prasat. Zvíŕata jsme rozdělili do čtyř skupin. Skupina A- autotransplantace $(\mathrm{n}=3)$, skupina B- allotransplantace s podáním tacrolimu $(\mathrm{n}=7)$, skupina $\mathrm{C}$ - na kombinované 
imunosupresi s tacrolimem a sirolimem $(\mathrm{n}=8)$, a kontrolní skupina bez imunosuprese $(\mathrm{n}=6)$. Výsledky: V první skupině jsme měli vysoký počet cévních komplikací, $67 \%$ (12 z 18). Ve druhé skupině jsme zredukovali počet komplikací na $12 \%$ (3 z 25). V druhé části studie měla nejkratší přežívání skupina $\mathrm{D}$ a nejdelší skupina $\mathrm{A}$. V obou léčených skupinách $(B+C)$ jsme $\mathrm{z}$ hlediska přežívání nenašli žádnou významnou odlišnost. Ze získaných výsledků můžeme konstatovat, že jednovrstevný pokračující steh je bezpečný pro všechny typy střevních anastomóz. Cévní rekonstrukce na centrální řečiště je pro přežití štěpu bezpečnější.

\section{Acknowledgements}

The work was supported by Grant No. NR/ 8896-3 awarded by the Internal Grant Agency of the Ministry of Health of the Czech Republic.

\section{References}

Alessiani M, De Ponti F, Fayer F, Abbiati F, Zonta S, Zitelli E, Arbustini E, Morbini P, Poggi N, Klersy C, Blangetti I, Dionigi P, Zonta A 2003: The influence of surgery, immunosuppressive drugs, and rejection, on graft function after small bowel transplantation: a large-animal study. Transplant Int 16: 327-335

Alessiani M, Spada M, Vaccarisi S, Ferrari P, Zanola S, Merli M, Iacona I, Noli S, Dionigi P, Zonta A 1997: Flexibility of the surgical model of intestinal transplantation in swine. Minerva Chir 52: 1017-1028

Brown DC 2003: Small intestine. In: Slatter DH (Ed): Textbook of Small Animal Surgery. 3rd ed. Saunders, Philadelphia, pp. 660-661

Calleja-Kempin J, Vazquez-Estevez J, Martin-Cavanna J, Jimenez-Almonacid P, De Agustin JC 1998: Vascular thrombosis in small bowel transplantation: a comparative study in pigs. Transplant Proc 30: 2646

Crha M, Lorenzová J, Urbanová L, Fichtel T, Nečas A 2008: Two techniques of intestinal wall suture in surgical treatment of ileus in dogs and the importance of omentalisation. Acta Vet Brno 77: 263-267

Ellison GW 1998: Intestinal resection and anastomosis In: Bojrab MJ (ed): Current Techniques in Small Animal Surgery. 4th ed. Lippincott Williams and Wilkins, Baltimore, pp. 248- 254

Gatti S, Rossi G, Plazzini AA, Reggiani P, Caccamo L, Gridelli B, Lucianetti A, Paone G, Galmarini D 1994: Orthotopic Liver-Small Bowel Allotransplantation- Surgical Technique in the Pig. Transplant Proc 26: $1627-$ 1628

Hendlung CS 2002: Surgery of the small intestine: general principles and techniques. In: Fossum TW (ed): Small Animal Surgery. 2nd ed. Mosby, St. Louis, pp. 369-398

Murase N, Demetris AJ, Kim DG, Todo S, Fung JJ, Starzl TE 1990: Rejection of multivisceral allografts in rats: a sequential analysis with comparison to isolated orthotopic small-bowel and liver grafts. Surgery 108: 880 889

Oliverius M, Balaz P, Kudla M, Valsamis A, Cap J, Adamec M 2009: Small bowel graft revascularization in experiment. Bratisl Lek Listy 110: 63- 66

Pascher A, Kohler S, Neuhaus P, Pratschke J 2008: Present status and future perspectives of intestinal transplantation. Transpl Int 21: 401-414

Ruiz P, Bagni A, Brown R, Cortina G, Harpaz N, Magid MS, Reyes J 2004: Histological criteria for the identification of acute cellular rejection in human small bowel allografts: results of the pathology workshop at the VIII International Small Bowel Transplantation Symposium. Transplant Proc 36: 335

Ruiz P, Kato T, Tzakis A 2007: Current status of transplantation of the small intestine. Transplantation 83: 1-6

Weisman DL, Smeak DD, Birchard SJ, Zweigart SL 1999: Comparison of a continuous suture pattern with a simple interrupted pattern for enteric closure in dogs and cats: 93 cases (1991-1997). J Am Vet Med Assoc 214:1507- 1510 


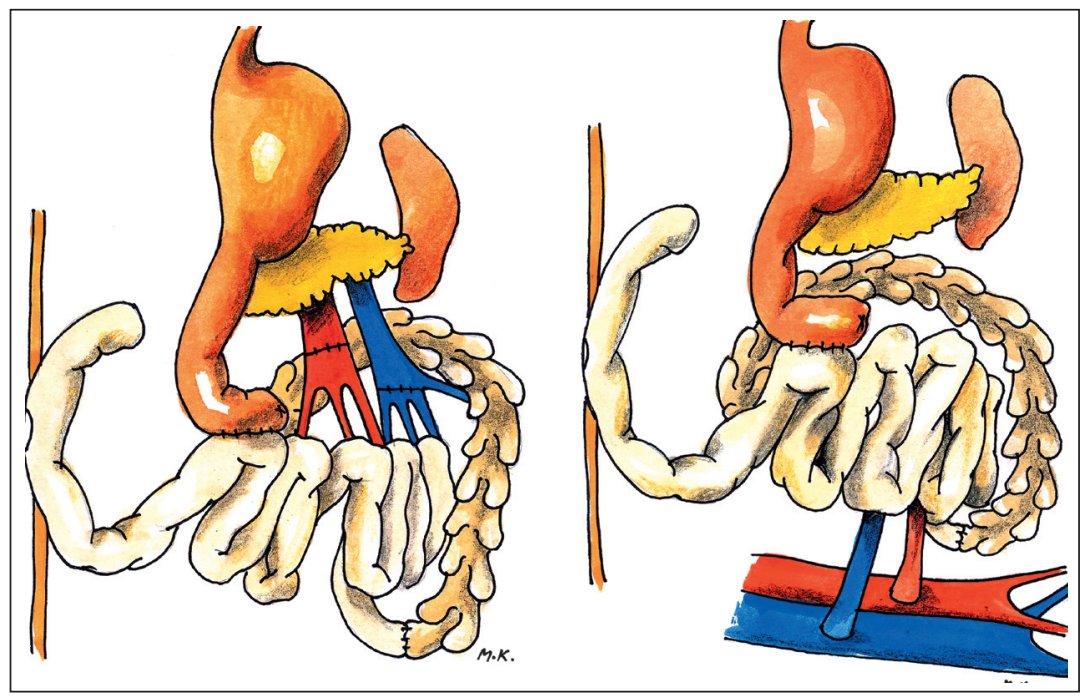

Fig. 1. Technique of vascular anastomoses construction. Left, anastomoses constructed to the mesenteric vessel bed. Right, anastomoses sutured to the aorta and vena cava inferior. Schematic representation of chimney jejunostomy. (Illustrations by Marie Kolářová - M.K.).

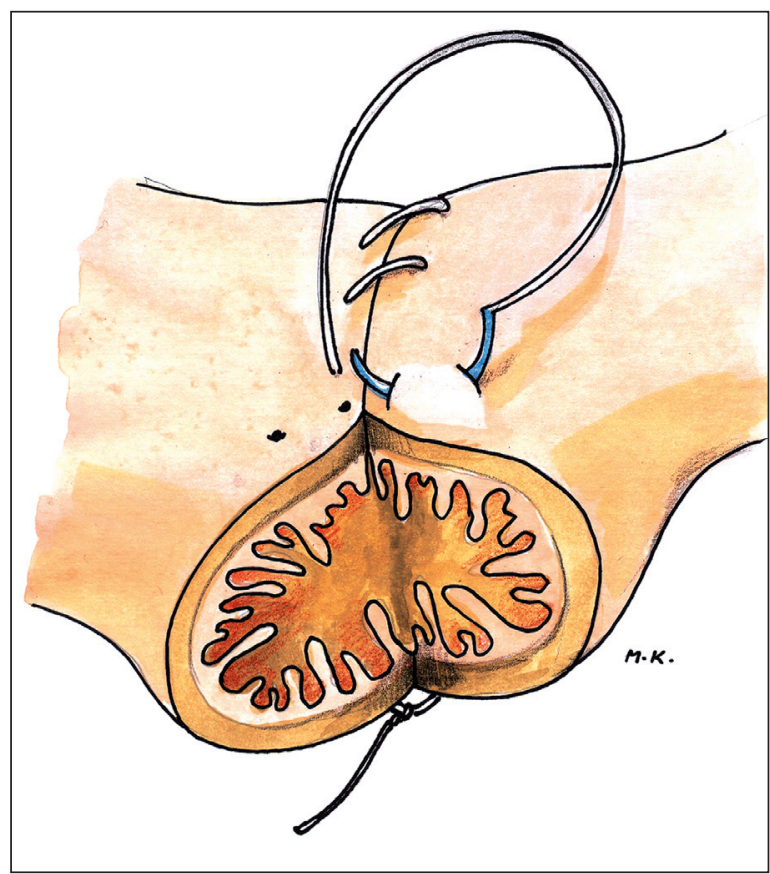

Fig. 2. Schematic representation of the anastomosis construction with single-layer monofilament continuous suture. (Illustration by Marie Kolářová - M.K.) 


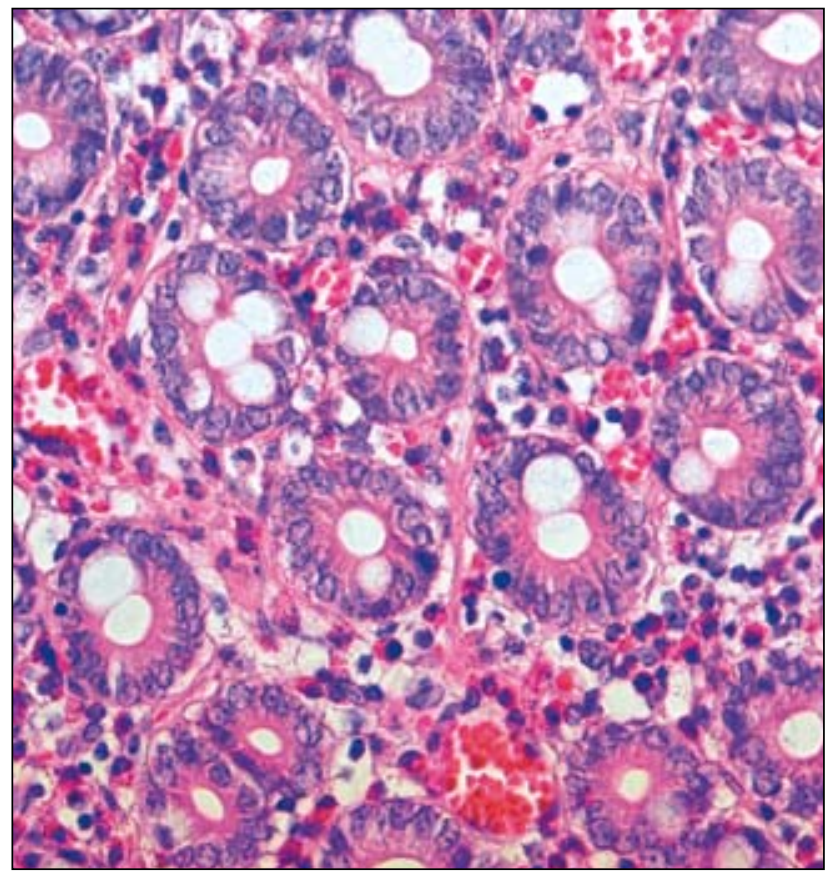

Fig. 3. Mild acute rejection with scattered lymphoplasmatic inflammatory cells in lamina propria and minimal crypt injury with several apoptotic cells $(H \& E$, original magnification $\times 200)$.

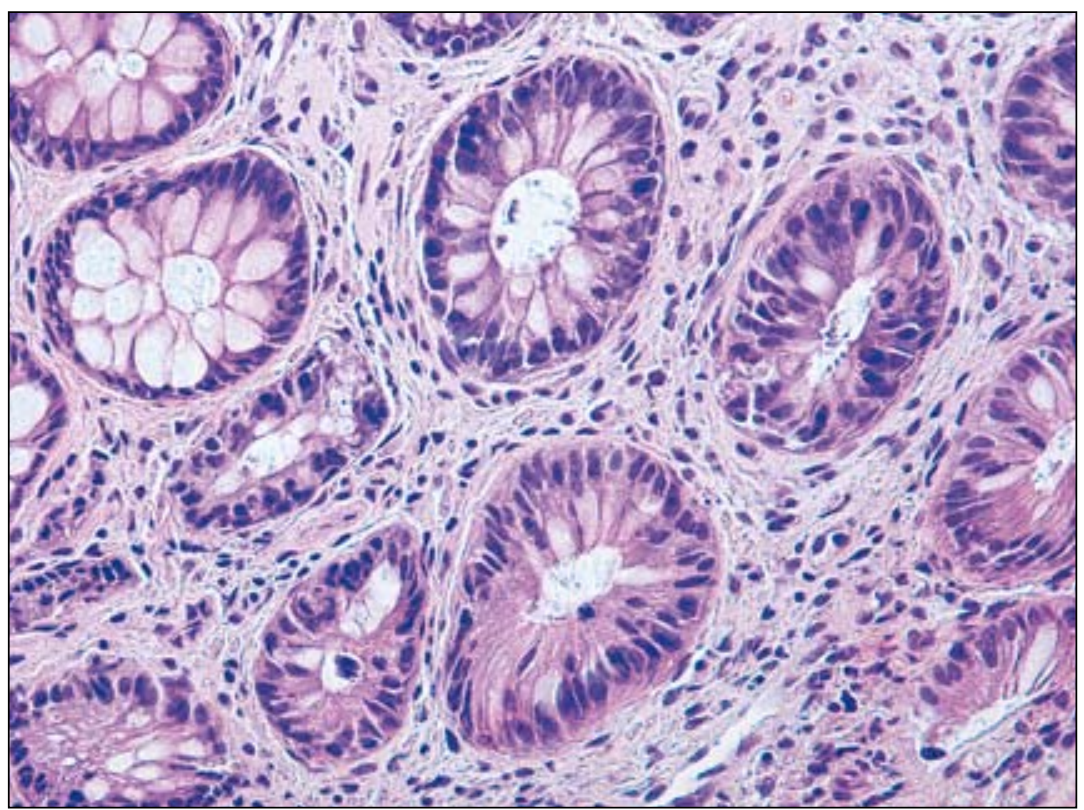

Fig. 4. Moderate acute rejection. Dispersed inflammatory infiltrate in lamina propria and increased crypt apoptosis with focal confluent apoptotic injury $(\mathrm{H} \& \mathrm{E}$, original magnification $\times 200)$. 


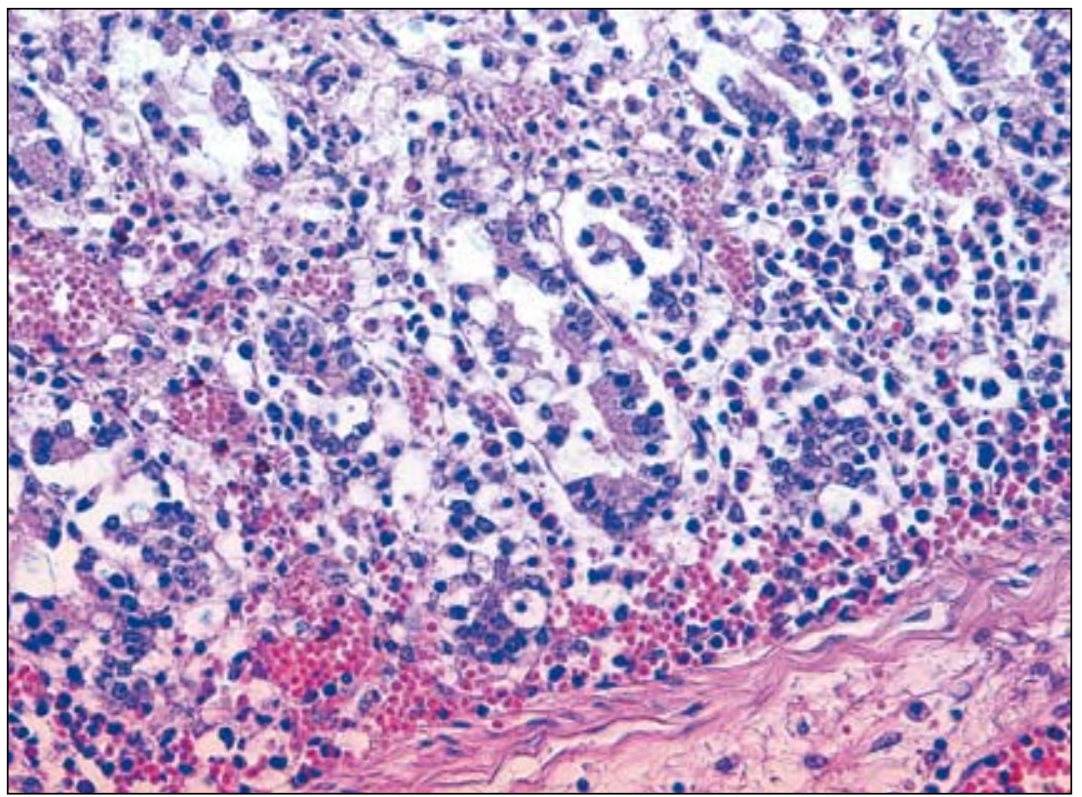

Fig. 5. Severe acute rejection is characterized by marked epithelial damage with severe diffuse inflammation and crypt destruction (H\&E, original magnification $\times 100)$. 